
\title{
$\begin{array}{ll}\text { Research Square } & \text { Preprints are preliminary reports that have not undergone peer review. } \\ \text { They should not be considered conclusive, used to inform clinical practice, } & \text { or referenced by the media as validated information. }\end{array}$
}

\section{Molecular detection of Epstein-Barr virus in paraffin- embedded tissue samples of patients suffering gastric cancer in Ahvaz, Iran: a case-control study}

\section{Mehdi Gharibzadeh}

Ahvaz Jundishapur University of Medical Sciences: Ahvaz Jondishapour University of Medical Sciences Azarakhsh Azaran ( $\nabla$ azarakhsh.azaran@yahoo.com )

Ahvaz Jundishapur University of Medical Sciences: Ahvaz Jondishapour University of Medical Sciences https://orcid.org/0000-0002-0741-8915

\section{Shahram Jalilian}

Ahvaz Jundishapur University of Medical Sciences: Ahvaz Jondishapour University of Medical Sciences

\section{Seyed Saeid Seyedian}

Ahvaz Jundishapur University of Medical Sciences: Ahvaz Jondishapour University of Medical Sciences Manoochehr Makvandi

Ahvaz Jundishapur University of Medical Sciences: Ahvaz Jondishapour University of Medical Sciences

\section{Research Article}

Keywords: Gastric cancer, Gastric ulcer, Epstein-Barr virus, EBER, EBNA1, Iran

Posted Date: January 19th, 2021

DOI: https://doi.org/10.21203/rs.3.rs-147824/v1

License: (c) (1) This work is licensed under a Creative Commons Attribution 4.0 International License. Read Full License 


\section{Abstract \\ Background}

Gastric cancer (GC) is the third most common cause of cancer-related mortality. Epstein-Barr virus (EBV) is associated with gastric cancer. The present research was performed to investigate the prevalence of EBV-associated gastric cancer (EBVaGC) among Iranian patients.

\section{Materials and Methods}

Seventy formalin-fixed paraffin-embedded (FFPE) cases of gastric cancer and 30 FFPE cases of gastric ulcer were studied from 2011-2018 in the case-control study. The specimens were investigated for the presence of the EBV genome by Nested-PCR for EBNA1. The positive samples for the EBNA1 region were again tested for the EBER gene by the PCR method. Positive samples were sequenced and aligned to construct the EBV phylogenetic tree.

\section{Results}

Five out of 70 cases (7\%) indicated positive results for EBV by EBNA1, while all EBNA1 positive samples were negative for EBER. Additionally, EBV was detected in none of the gastric ulcer patients. The mean age for patients with EBV-positive gastric carcinomas was 64.5 years. Three (60\%) male patients and 2 (40\%) female cases were positive for EBV. Three out of 24 (60\%) diffuse-type cases were EBV associated,

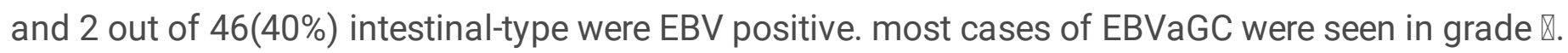

\section{Conclusion}

The present study shows that the frequency of EBVaGC in Iran is low. Differences in EBVaGC incidence in different countries may represent epidemiologic factors and dietary habits. Further analysis of clinical pathology characteristics of EBVaGC using a greater number of cases will offer useful insights into its etiology.

\section{Introduction}

Gastric cancer(GC) is the third most common cause of cancer-related mortality accounted for $8.2 \%$ of all cancer deaths and one of the most common tumors of the gastrointestinal tract worldwide $(1,2)$. There are the highest rates in Eastern Asia, followed by Central and Eastern Europe, and the lowest in North America and Western Africa (3). Gastric cancer is a combination of multifactorial disease. The common risk factors of GC include infectious agents such as Helicobacter pylori (HP), smoking, high salty-diets, susceptibility to hereditary gastric cancer syndrome (4). At the beginning of the 1990s, the association 
between Epstein-Barr virus (EBV) and gastric carcinomas was found. (2) Epstein-Barr virus associated gastric cancer (EBVaGC) comprises approximately $10 \%$ of gastric carcinomas.(5)

EBV is a doublestranded DNA virus, also known as human herpes virus 4.It is a gamma-herpes as a member of the Herpesviridae family with oncogenic activity and responsible for approximately $1.8 \%$ of all human cancers, including malignancies of both lymphoid and epithelial cell origin such as Hodgkin lymphoma, Burkitt lymphoma, NK/T cell lymphoma, and nasopharyngeal carcinoma and gastric carcinoma (2).

The oral route is the primary route of the EBV transmission. However, it has been reported that organ transplantation and blood transfusion can lead to EBV spread.(6) Primary infection in early adulthood leads to the establishment of life-long latency in memory B cells (7). During a latent EBV infection, the viral genome persists for life-long in multiple circular episomes inside the infected cell nucleus (8). EBV can exhibit one of four latency programs that differ in the expression of particular EBV-encoded genes. EBVaGC belongs to latency type I or II, in which EBNA-1, LMP-2A, EBERs, BARTs, and BART miRNAs are expressed. (9)EBNA-1 is crucial for the maintenance of the episomal viral genome in infected cells during cell division (9). In gastric carcinoma cells, EBV is not integrated into the host genome (9).

Several published meta-analyses are addressing the prevalence and association of EBV among gastric cancer patients, however, some important variables such as gender, type of samples, and tumor anatomical location did not include in their meta-analysis. Advanced stage, cardiac tumor localization, older age, and less differentiated histology are adverse prognostic indicators in the patients with GC (2).

To date, the mechanisms of EBV-associated gastric cancer are still not comprehensively clarified. Despite these findings, the importance of EBV in gastric carcinogenesis has long been underestimated. In this study, the presence of EBV in GC tissue samples was studied from paraffin-embedded malignant tissues in Iranian patients with GC for finding the relationship between those viruses and gastric cancer.

\section{Materials And Methods}

\section{Ethical issues}

The ethics committee approved the present research of the Ahvaz Jundishapur University of Medical Sciences, Ahvaz, Iran, under reference number: IR.AJUMS.MEDICINE.REC.1397.001.

\section{Study population}

This was a case-control study of 100 participants with gastric cancer and gastric ulcer aged between 1989 years, referred to Imam Khomeini Hospital, Ahvaz-Iran from 2011-2018. This research was designed in that two groups of patients were randomly selected based on the presence or absence of GC and assigned into case and control groups. Formalin-fixed paraffin-embedded (FFPE) tissues are the most common specimen stored in pathology laboratories. All samples were collected from the archives and 
diagnostic accuracy of gastric cancer and ulcer were confirmed after endoscopy and biopsy, and after gastrectomy by a pathologist.

We examined 70 paraffin-embedded tissue blocks from gastric cancer patients as a test group and 30 paraffin- embedded tissues block from gastric ulcer patients as a control group. The inclusion criteria for the case group: all of the gastric carcinoma untreated patients with age $>18$ years. The exclusion criteria: The patients with severe gastritis or atrophic and treated patient. The inclusion and exclusion criteria for the control group study were a gastric ulcer and low/moderate/high grade of metaplasia or dysplasia respectively.

\section{Deparaffination samples}

One hundred paraffin blocks were sectioned $10 \mu$ m-thick about 10 times. Deparaffination was done by xylene and ethanol (Germany, Merk). Initially, all the specimens were placed in microtubes then xylene was added and kept at $45^{\circ} \mathrm{C}$ for $15 \mathrm{~min}$ followed by centrifuge at $14000 \mathrm{rpm}$. This stage was repeated. The supernatant was discarded and $1 \mathrm{ml}$ absolute ethanol was added to the precipitate and stored at room temperature for $10 \mathrm{~min}$ and centrifuged again at $14000 \mathrm{rpm}$ for 1 minute. The supernatant was discarded. This process was repeated by adding $70 \%$ ethanol, followed the same condition and again this process was repeated by adding $50 \%$ ethanol, followed the same condition. Finally, the supernatant was discarded and all microtubes were placed at $65^{\circ} \mathrm{C}$ for $5 \mathrm{~min}$ to vaporize the ethanol residue and the pellet was used in DNA extraction.(10)

\section{DNA extraction}

DNA was extracted by the standard proteinase K-sodium dodecyl sulfate (SDS) method, followed by phenol-chloroform purification, and the purity and concentration of viral DNA were measured by a NanoDrop spectrophotometer (Thermo Fisher Scientific, USA) $(11,12)$. The extracted DNA was stored at $-20^{\circ} \mathrm{C}$ until PCR amplification.

\section{Detection of EBV by Nested PCR for EBNA 1 region}

Nested-PCR test was performed in two steps of primary PCR and Nested for detection of EBNA 1 (EpsteinBarr virus nuclear antigen-1). The primers for primary PCR was a 609 bp region of EBNA-1 and primers for Nested PCR was a 308 bp region of EBNA-1 described in Table 1. The first round of PCR was performed in a $25 \mu \mathrm{l}$ mixture, containing $10 \mu \mathrm{l}$ of extracted DNA, $12 \mu \mathrm{l} \mathrm{PCR}$ master mix (2x), $1 \mu \mathrm{l}(10 \mathrm{nM})$ of each primer sequence, and $1 \mu \mathrm{l}$ distilled water. Cycling conditions are as follows: denaturation at $95^{\circ} \mathrm{C}$ for $10 \mathrm{~min}$, followed by amplification cycle at $95^{\circ} \mathrm{C}$ for $30 \mathrm{sec}, 53^{\circ} \mathrm{C} 30 \mathrm{sec}, 72{ }^{\circ} \mathrm{C} 30 \mathrm{sec}$ for $30 \mathrm{cycles}$, and a final extension at $72{ }^{\circ} \mathrm{C} 10 \mathrm{~min}$. The second round was carried out with $5 \mu$ of the first-round product, $1 \mu \mathrm{l}$ $(10 \mathrm{nM})$ of each primer sequence, $12 \mu \mathrm{l} \mathrm{PCR}$ master mix (2x), and $6 \mu$ l distilled water. Cycling conditions are as follows: denaturation at $95^{\circ} \mathrm{C}$ for $10 \mathrm{~min}$, followed by amplification cycle at $95^{\circ} \mathrm{C}$ for $30 \mathrm{sec}, 62^{\circ} \mathrm{C}$ $30 \mathrm{sec}, 72{ }^{\circ} \mathrm{C} 30 \mathrm{sec}$ for $30 \mathrm{cycles}$, and a final extension at $72{ }^{\circ} \mathrm{C} 10 \mathrm{~min}$. PCR product was subjected to electrophoresis on a $2 \%(0.5 \mu \mathrm{g} / \mathrm{ml})$ agarose gel, stained with DNA safe stain, and observed under ultraviolet light. The expected PCR product for the second round was $308 \mathrm{bp}$. 
We used the B95-8 cell line (EBV-transformed leukocytes) as a positive control, and a mixture of samples without DNA served as a negative control. (13)

\section{PCR for the EBER gene}

The positive samples for the EBNA1 region were again tested for the EBER gene of the EBV genome by PCR method. The PCR was performed in a $25 \mu$ mixture, containing $5 \mu$ l of extracted DNA, $12 \mu$ PCR master mix (2x), $1 \mu \mathrm{l}(10 \mathrm{nM}$ ) of each primer sequence, and $6 \mu$ listilled water. Cycling conditions are as follows: denaturation at $95^{\circ} \mathrm{C}$ for $10 \mathrm{~min}$, followed by amplification cycle at $95^{\circ} \mathrm{C}$ for $30 \mathrm{sec}, 48{ }^{\circ} \mathrm{C} 30$ $\mathrm{sec}, 72{ }^{\circ} \mathrm{C} 30 \mathrm{sec}$ for 30 cycles and, a final extension at $72{ }^{\circ} \mathrm{C} 10 \mathrm{~min}$. The expected PCR product for this test was $150 \mathrm{bp}$. PCR product was subjected to electrophoresis on a $2 \%$ agarose gel, stained with DNA safe stain, and observed under ultraviolet light. Primers used for two steps of PCR are reported in Table 1.

Table 1

EBV gene-specific primers used for Nested-PCR and PCR amplification

\begin{tabular}{|c|c|c|c|c|}
\hline $\begin{array}{l}\text { Primers } \\
\text { name }\end{array}$ & Sequences $\left(5^{\prime}-3^{\prime}\right)$ & $\begin{array}{l}\text { Product } \\
\text { size }\end{array}$ & Location & References \\
\hline EBNA-1-F1 & GTA GAA GGC CAT TTT TCC AC & 609 bp & $\begin{array}{l}95502 \text { to } \\
95521\end{array}$ & $(14)$ \\
\hline EBNA-1-R1 & CTC CAT CGT CAA AGC TGC & & $\begin{array}{l}96093 \text { to } \\
96110\end{array}$ & \\
\hline EBNA-1-F2 & $\begin{array}{l}\text { AGA TGA CCC AGG AGA AGG CCC } \\
\text { AAG G }\end{array}$ & 309 bp & $\begin{array}{l}95705 \text { to } \\
95729\end{array}$ & $(14)$ \\
\hline EBNA-1-R2 & $\begin{array}{l}\text { CAA AGG GGA GAC GAC TCA ATG } \\
\text { GTG }\end{array}$ & & $\begin{array}{l}95989 \text { to } \\
96012\end{array}$ & \\
\hline EBER-F & GAT CCA AAC TTT AGT TTT AG & 153 bp & 6796 to 6815 & $(15)$ \\
\hline EBER-R & CGC AAC CGT AAC TCT ATA C & & 6927 to 6945 & \\
\hline
\end{tabular}

\section{Nucleotide Sequencing and phylogenetic analysis}

The purified products from the second round of PCR amplification for EBNA1 in both the forward and reverse directions were sequenced using an ABI 3730 XL DNA sequencer (BIONEER's Custom Services Sequencing Service). Analysis and alignment of forward and reverse sequences were performed by SnapGene sequence alignment editor version 3.2.1. The sequences were deposit in the GenBank database under the accession numbers: MT360999, MT361000, MT361000, MT361002, and MT361003. For phylogenetic analysis, MEGA 7 software was utilized. The Maximum likelihood method with Tamura Nei-model was used for the construction phylogenetic tree. 1000 bootstrap replicates performed the confidence level of evolutionary distances.

\section{Statistical analysis}

SPSS software version 26 (SPSS Inc, Chicago, IL, USA) was used for data analysis. Analyses of data were performed using the $\mathrm{K}_{2}$ test. Furthermore, Odds Ratio and Confidence Intervals were used for 
comparing differences between groups. The P-value smaller than 0.05 was considered statistically significant.

\section{Results}

\section{Patients characteristics and clinical pathology}

The research was amid to evaluation of the frequency of Epstein-Barr virus in tissue samples of patients suffering gastric cancer in Ahvaz, Iran that enrolled 70 patients with gastric cancer as a test group and 30 patients who suffered from gastric ulcer as a control group. The patient group included 26 women (34\%) and 44 men (66\%) with a mean age of $64.5 \pm 17$ years old and the control group included $15(50 \%)$ women and $15(50 \%)$ men with a mean age $58.1 \pm 19.4$ of years old. Minimum and maximum age for male were 19 and 89 years old and for female were 20 and 82 years old.

The sampling method was performed in 35 patients (79\%) using biopsy by endoscopy and 15 cases ( $21 \%)$ by gastrectomy. In the control group, all samples were prepared by endoscopy. It should be noted that all samples in the control group were negative in terms of dysplasia and metaplasia. Frequency different types and different grades of Gastric Cancer Samples are shown in Figs. 1 and 2 respectively.

\section{Prevalence of EBV positive cases}

EBV (EBNA 1) was detected in five out of 70 cases (7\%) which were considered as EBVaGC. (Fig. 3). These positive cases were negative for the EBER gene. All samples of the control group were negative for EBNA 1. Table 1 shows the distribution of EBV-Positive and EBV negative according to age, sex in Gastric Cancer. The results of the Frequency type and grade of carcinoma and PCR result are presented in Tables 2 and 3 respectively.

\section{Factors associated with EBV positive cases}

Gender and age

The mean age for EBV-positive patients was $65.8 \pm 15.2$ years. EBV positive cases include $2(40 \%)$ female and $3(60 \%)$ male. (Table 1$)$ 
Table 1

The distribution of EBV-Positive and EBV-negative according to age, sex in Gastric Cancer

\begin{tabular}{|llll|}
\hline & EBV-Negative & EBV-Positive & P-value \\
\hline Age & $64.5 \pm 17$ & $65.8 \pm 15.2$ & 0.282 \\
\hline Male & $41(63)$ & $3(60)$ & $>0.990$ \\
\cline { 1 - 2 } Female & $24(37)$ & $2(40)$ & \\
\hline
\end{tabular}

Histological type

Based on Lauren's classification, 3 out of 24 (60\%) diffuse-type cases were EBV associated, and 2 out of

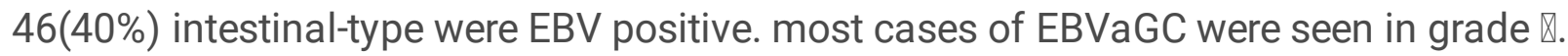

Table 2

The Frequency type of carcinoma and PCR result

\begin{tabular}{|llll|}
\hline Type of Adenocarcinoma & Num (\%) & EBV-Positive & P-value \\
\hline Intestinal & $46(65)$ & $2(40)$ & $>0.990$ \\
\cline { 1 - 3 } Diffuse & $24(35)$ & $3(60)$ & \\
\hline
\end{tabular}

Table 3

The Frequency grades of carcinoma and PCR result

\begin{tabular}{|c|c|c|c|}
\hline Grade of Adenocarcinoma & Num (\%) & EBV-Positive & P-value \\
\hline प & $15(21)$ & 2 & \multirow[t]{4}{*}{0.794} \\
\hline ( & $21(30)$ & 1 & \\
\hline प & $24(34)$ & 1 & \\
\hline Unclassified & $10(15)$ & 1 & \\
\hline
\end{tabular}

\section{Sequencing result}

The sequence of PCR products that were amplified by EBNA 1 primers was compared to the EBNA 1 reference gene sequence registered to GenBank. PCR amplicon sequences of the positive samples were identical to the EBNA 1 reference gene and molecular Phylogenetic analysis was done for these sequences (Fig. 3, 4).

For phylogenetic analysis, the evolutionary history was inferred by using the Maximum Likelihood method based on the Tamura-Nei model. The tree with the highest log likelihood (-555.19) is shown. The percentage of trees in which the associated taxa clustered together is shown next to the branches. Initial 
tree(s) for the heuristic search were obtained automatically by applying Neighbor-Join and BioNJ algorithms to a matrix of pairwise distances estimated using the Maximum Composite Likelihood (MCL) approach, and then selecting the topology with superior log likelihood value. The tree is drawn to scale, with branch lengths measured in the number of substitutions per site. The analysis involved 16 nucleotide sequences. Codon positions included were $1 s t+2 n d+3 r d+$ Noncoding. All positions containing gaps and missing data were eliminated. There were a total of 284 positions in the final dataset. Evolutionary analyses were conducted in MEGA7. The sequences obtained in this project had a 100\% similarity to strain MK164621.1 from Canada (Fig. 3).

Table 4

Clinical characteristics of EBV associated gastric cancer

\begin{tabular}{|lllll|}
\hline Patient No. & Gender & Age & Type of adenocarcinoma & Grade of adenocarinoma \\
\hline 1 & M & 55 & Diffuse & Unclassified \\
\hline 2 & M & 77 & Intestinal & $\square$ \\
\hline 3 & F & 78 & Intestinal & $\square$ \\
\hline 4 & F & 41 & Diffuse & $\square$ \\
\hline 5 & M & 78 & Diffuse & $\square$ \\
\hline
\end{tabular}

\section{Discussion}

Epstein-Barr virus is the cause of infectious mononucleosis. Many documents show EBV is associated with a variety of malignant neoplasms including nasopharyngeal carcinoma (NPC), Burkitt lymphoma, Hodgkin lymphoma, nasal T/NK cell lymphoma, and B cell-lymphoma in the immunosuppressed and gastric cancer patient. Although the global prevalence of EBV has been consistently reported in $95 \%$ of adults, the proportion of tumors associated with this virus has been reported differently in different regions (16) .

Gastric cancer is the third most common cause of cancer-related mortality and one of the most common tumors of the gastrointestinal tract worldwide $(1,2)$. The present work assessed the prevalence of EpsteinBarr virus in tissue samples of patients with gastric cancinoma in Ahvaz, Iran.

To date, several studies have attempted to discover the role of EBV infection in the progression of gastric cancer. EBV enters B lymphocytes in oropharyngeal lymphoid tissues. The virus then enters the gastric epithelial cells, either by the cell-to-cell contact between B lymphocytes and gastric epithelial cells or through direct entry into the gastric epithelial cells..(2)

According to the results of the study, the frequency of EBV in patients with gastric cancer in Ahwaz is $7 \%$ but not in the benign ulcer cases. The diagnosis of EBV-associated gastric cancer is confirmed by the presence of the EBNA1 gene within the gastric cancer cells and its absence in the control group cases. 
The association of EBV and gastric cancer was first reported in 1990. Now, various studies from different countries show EBV is related to $10 \%$ of gastric cancer patients. EBV-associated GC differs in various geographical regions, e.g, 6.4 \% in China, 8.1 \% in Mexico, $19.5 \%$ in German, 5.6\% in Korea, $12 \%$ in the United States, $8.5 \%$ in France, $13 \%$ in Colombia, and $11.3 \%$ in Brazil. (16). The results of this study compared with previous studies in Iran. The frequency of EBV in patients with gastric cancer in Tehran, Sari, and Kerman was reported $7 \%, 3 \%, 11 \%$, respectively. (16-18)

Since the prevalence of EBV-associated gastric cancer is lower in areas with a high incidence of gastric cancer and in areas with a low prevalence of gastric cancer is more and because Ahvaz is the region with a high incidence of Gastric cancer. $(19,20)$ In contrast, Amoueian reported a very high prevalence $(62 \%)$ of EBVassociated GC in the Northeast of Iran compared with other areas of the World and showed an important correlation between EBV infection and incidence of Gastric cancer. Some investigators checked EBV in GCs and suggested that there are ethnic differences in tumor virology and pathogenesis. (21)

EBV-associated gastric cancer varies in different countries, it seems that economic conditions are not an important variable for EBV associated gastric cancer because low and high frequencies were found in both developed and developing countries (16). Therefore, these variations in EBV-associated occurrence of GC in different areas may represent epidemiological and clinicalopathological factors; dietary habits and genetic.; dietary habits and genetic. (21) We should consider that the low number of positive cases in our study might be the reason for the insignificant result in the analysis ( $P$-value $=0.318)$.

EBV encoded genes in EBV associated gastric carcinoma as follows: EBNA-1, LMP1, LMP2, EBERs and, miRNAs reported in the majority of tumor cells and EBNA2, 3A, 3B, 3C, LP and not reported in most tumor cells of GC. EBNA-1 targets a single copy highly conserved gene and is important for the long-term maintenance of the virus in dividing cells. The possible contribution of EBV to GC pathogenesis is largely unknown. It has been suggested that EBV may be associated with the majority of the cases, including those diagnosed as EBV negative (EBNA1) or EBER negative by a mechanism of hit-and-run. Early during oncogenesis, viral genes are necessary for the initiation of disease. Gradually, the viral genome is lost to avoid the immune response and host mutations accumulate in the proto-oncogenic cell. (15) Based on this hypothesis, the negation of the EBER gene in our study can be justified. In the same way, Lee and coworkers in the study from Korea showed that the presence of EBV was indicated in 3 samples $(3.30 \%)$ by EBER-ISH, 26 samples (28.57\%) by Nested PCR, and 3 samples (3.30\%) by EBER PCR.(15) In this way, Lee and colleagues found that EBV was detected in 4 of 40 cases (10\%) of gastric carcinoma whereas LMP1, was negative. (22)

In most studies, sex differences favor men, but not were some studies have shown a significant relationship between sex and EBVaGC. (23) In this study, EBV-associated gastric cancer was seen more in men, but according to the statistical analysis of the results, not was a significant relationship found between sex and EBVaGC-. (P-value > 0.99) (Table 1).

The mean age for patients with EBV-positive gastric carcinomas was 65.8 years. However, in the present study, the highest incidence of EBV-positive gastric carcinomas was in the age group of 70-79 years 
(4.2\%) but there is no significant statistical was seen between age and EBV-positive gastric carcinomas $(P$-value $=0.282)$ (Table 1$)$. These findings are in accord with results reported by other studies investigating from Portugal (24), Russian(25), Mexico, and Several cities in Iran. $(17,18,20)$ However, several studies were shown a tendency to involvement at lower age (Kazakhstan and Colombia). $(26,27)$ or higher age (Mexico and Malaysian). $(28,29)$

The division of gastric cancer is as follows: 1- Adenocarcinoma 2- Lymphoma 3- Stromal sarcoma 4Liposarcoma 5- Squamous cell carcinoma. More than $95 \%$ of gastric cancers are adenocarcinomas (17, 30). Laurén divided the histology of gastric cancer into two groups, i.e., the intestinal- type and the diffuse- type; later, the indeterminate type was included to describe uncommon histology. Most studies showed the intestinal type to be the most common, followed by the diffuse and then indeterminate type. (31) Several constant clinical-pathological features were seen in EBV associated gastric cancer such as moderately to the poorly differentiated type of gastric cancer and predisposition to upper stomach (16). As shown in Table 2 in the present study all patients had adenocarcinoma (65\% intestinal and 35\% diffuse type). The prevalence of EBVaGC in diffuse type gastric carcinoma was more in our study, a fact which was seen in most studies of Latin America $(28,32)$ and some countries in Asia such as Korea (33), China, (34) and India (35). Abdirad and co-workers in a study from Iran showed the proportion of EBV-GC cases in diffuse- type was higher than intestinal- type $(P>0.05)$. (20)

Some studies have demonstrated a better prognosis of EBVaGC than for Gastric carcinoma with EBV negative. Studies reported that there are also many prognostic factors in GC that affect survival, such as grade, lymphovascular invasion, resection type, and performance status. In this research, most cases of EBV have been observed in grade 1 cancers(36).

The present study indicates that the prevalence of EBV-associated gastric carcinoma in Iran is low. Differences in the occurrence of EBV-associated gastric carcinoma in different countries can represent epidemiological factors and dietary trends. Regarding the significant mortality rate of GC, EBV should be more considered in this group in the different geographic areas to receive appropriate specific treatment for EBV.

\section{Conclusion}

Our study showed the prevalence rate of 7\% EBV gastric cancer patients. Considering this finding, we concluded that EBV could be associated with gastric cancer, and is not accidentally found in gastric cancer. Further studies with larger samples are needed to obtain a better estimate of EBV and to reveal the significance and repercussions of EBV in patients with gastric carcinoma.

\section{Declarations}

\section{Availability of data and materials}


The datasets during and/or analysed during the current study available from the corresponding author on reasonable request.

\section{Competing interests}

The authors declare that they have no competing interests.

\section{Funding}

This study financially supported by Infectious and Tropical Diseases Research Center, Health Research Institute, Ahvaz Jundishapur University of Medical Sciences, Ahvaz, Iran.

\section{Authors' contributions}

Azarakhsh Azaran: Analyzed and interpreted the patient data and writing the manuscript.

Mehdi gharibzadeh: Data collection and performed the virological examination.

Shahram Jalilian: Interpreted the patient data.

Seyed Saeid Seyedian: Contributor in writing the manuscript.

Manoochehr Makvandi:Revised the manuscript.

All authors read and approved the final manuscript.

\section{Acknowledgment}

This paper is issued the thesis from MSc by Mehdi Gharibzadeh with registration number OG-9801 and financially supported by Infectious and Tropical Diseases Research Center, Health Research Institute, Ahvaz Jundishapur University of Medical Sciences, Ahvaz, Iran.

\section{References}

1. Chen X-Z, Chen H, Castro FA, Hu J-K, Brenner H. Epstein-Barr virus infection and gastric cancer: a systematic review. Medicine. 2015;94(20).

2. Tavakoli A, Monavari SH, Solaymani Mohammadi F, Kiani SJ, Armat S, Farahmand M. Association between Epstein-Barr virus infection and gastric cancer: a systematic review and meta-analysis. BMC Cancer. 2020;20:1-14.

3. Kalniṇa Z, Meistere I, Kikuste I, Tolmanis I, Zayakin P, Linē A. Emerging blood-based biomarkers for detection of gastric cancer. World journal of gastroenterology. 2015;21(41):11636.

4. Wang F-H, Shen L, Li J, Zhou Z-W, Liang H, Zhang X-T, et al. The Chinese Society of Clinical Oncology (CSCO): clinical guidelines for the diagnosis and treatment of gastric cancer. Cancer Communications. 2019;39(1):10. 
5. Naseem M, Barzi A, Brezden-Masley C, Puccini A, Berger MD, Tokunaga R, et al. Outlooks on EpsteinBarr virus associated gastric cancer. Cancer treatment reviews. 2018;66:15-22.

6. Smatti MK, Al-Sadeq DW, Ali NH, Pintus G, Abou-Saleh H, Nasrallah GK. Epstein-Barr virus epidemiology, serology, and genetic variability of LMP-1 oncogene among healthy population: an update. Frontiers in oncology. 2018;8:211.

7. Majerciak V, Yang W, Zheng J, Zhu J, Zheng Z-M. A genome-wide Epstein-Barr virus polyadenylation map and its antisense RNA to EBNA. Journal of virology. 2019;93(2):e01593-18.

8. Yates J, Warren N, Reisman D, Sugden B. A cis-acting element from the Epstein-Barr viral genome that permits stable replication of recombinant plasmids in latently infected cells. Proceedings of the National Academy of Sciences. 1984;81(12):3806-10.

9. Shinozaki-Ushiku A, Kunita A, Fukayama M. Update on Epstein-Barr virus and gastric cancer. International journal of oncology. 2015;46(4):1421-34.

10. Bouzari M, Ghaderian Z, Kardi M, Talebi A, editors. Development of DNA extraction method for detection of dna of viruses in formalin fixed paraffin embedded tissues. Proceedings of The 4th national Biotechnology congress Islamic Republic of Iran; 2005.

11. Sadeghi F, Bokharaei-Salim F, Salehi-Vaziri M, Monavari SH, Alavian SM, Salimi S, et al. Associations between human TRIM22 gene expression and the response to combination therapy with Peg-IFNa-2a and ribavirin in Iranian patients with chronic hepatitis C. Journal of medical virology. 2014;86(9):1499-506.

12. Russell DW, Sambrook J. Molecular cloning: a laboratory manual: Cold Spring Harbor Laboratory Cold Spring Harbor, NY; 2001.

13. Sugiura M, Imai S, Tokunaga M, Koizumi S, Uchizawa M, Okamoto K, et al. Transcriptional analysis of Epstein-Barr virus gene expression in EBV-positive gastric carcinoma: unique viral latency in the tumour cells. British journal of cancer. 1996;74(4):625-31.

14. Xu M, Yao Y, Chen H, Zhang S, Xiang T, Cao S-M, et al. Genome sequencing analysis identifies highrisk Epstein-Barr virus subtypes for nasopharyngeal carcinoma. bioRxiv. 2018:486613.

15. Lee J, Park M, Lee MH, Woo HJ, Kim H-W, Yang JY, et al. Development of EBV-encoded small RNA targeted PCR to classify EBV positive diffuse large B-cell lymphoma (DLBCL) of the elderly. International journal of clinical and experimental pathology. 2015;8(7):7859.

16. Msc EF, Msc MRS, AP HAM. Prevalence and characteristics of Epstein-Barr virus-associated gastric cancer in Iran. Archives of Iranian medicine. 2014;17(11):767.

17. Ghasemi M, Abedian Kenari S, Torabizadeh Z, Iri N, Marjani J, Mirabi AM. The Relationship between Epstein-Barr Virus (EBV) and Virus-Encoded BARF-1 Gene in Gastric Adenocarcinoma. Journal of Mazandaran University of Medical Sciences. 2011;21(82):10-6.

18. Leila Z, Arabzadeh SA, Afshar RM, Afshar AA, Mollaei HR. Detection of Epstein-Barr Virus and Cytomegalovirus in Gastric Cancers in Kerman, Iran. Asian Pacific Journal of Cancer Prevention. 2016;17(5):2423-8. 
19. Sajadi A, Zahedi M, DARVISH MS, Nouraei M, ALI MM, Ghorbani A, et al. The first population-based cancer survey in Kerman Province of Iran. 2007.

20. Abdirad A, Ghaderi-Sohi S, Shuyama K, Koriyama C, Nadimi-Barforoosh H, Emami S, et al. EpsteinBarr virus associated gastric carcinoma: a report from Iran in the last four decades. Diagnostic Pathology. 2007;2(1):25.

21. Amoueian S, Attaranzadeh A, Gholamimoallem Z, Sadeghi M, Hashemi S-M, Allahyari A. EpsteinBarr virus infection in adult patients with gastric cancer in Northeast of Iran. Indian Journal of Medical and Paediatric Oncology. 2018;39(2):206.

22. Lee MA, Hong YS, Kang JH, Lee KS, You JY, Lee KY, et al. Detection of Epstein-Barr virus by PCR and expression of LMP1, p53, CD44 in gastric cancer. The Korean journal of internal medicine. 2004;19(1):43.

23. Camargo MC, Kim W-H, Chiaravalli AM, Kim K-M, Corvalan AH, Matsuo K, et al. Improved survival of gastric cancer with tumour Epstein-Barr virus positivity: an international pooled analysis. Gut. 2014;63(2):236-43.

24. Ribeiro J, Oliveira A, Malta M, Oliveira C, Silva F, Galaghar A, et al. Clinical and pathological characterization of Epstein-Barr virus-associated gastric carcinomas in Portugal. World journal of gastroenterology. 2017;23(40):7292.

25. Galetsky SA, Tsvetnov VV, Land CE, Afanasieva TA, Petrovichev NN, Gurtsevitch VE, et al. EpsteinBarr-virus-associated gastric cancer in Russia. International Journal of Cancer. 1997;73(6):786-9.

26. Alipov G, Nakayama T, Nakashima M, Wen C-Y, Niino D, Kondo H, et al. Epstein-Barr virus-associated gastric carcinoma in Kazakhstan. World Journal of Gastroenterology: WJG. 2005;11(1):27.

27. Carrascal E, Koriyama C, Akiba S, Tamayo O, Itoh T, Eizuru Y, et al. Epstein-Barr virus-associated gastric carcinoma in Cali, Colombia. Oncology reports. 2003;10(4):1059-62.

28. Herrera-Goepfert R, Reyes E, Hernández-Avila M, Mohar A, Shinkura R, Fujiyama C, et al. Epstein-Barr virus-associated gastric carcinoma in Mexico: analysis of 135 consecutive gastrectomies in two hospitals. Modern pathology: an official journal of the United States and Canadian Academy of Pathology, Inc. 1999;12(9):873.

29. Karim N, Pallesen G. Epstein-Barr virus (EBV) and gastric carcinoma in Malaysian patients. The Malaysian journal of pathology. 2003;25(1):45-7.

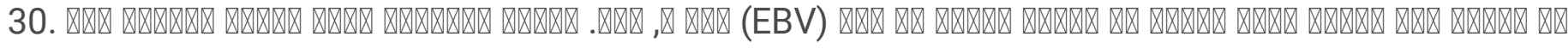
प्राप्र Relative Frequency of epstien barr Virus (EBV) DNA in breast cancer Samples from Ahvaz: : $2015 ;$

31. Berlth F, Bollschweiler E, Drebber U, Hoelscher AH, Moenig S. Pathohistological classification systems in gastric cancer: diagnostic relevance and prognostic value. World journal of gastroenterology: WJG. 2014;20(19):5679.

32. Corvalan A, Koriyama C, Akiba S, Eizuru Y, Backhouse C, Palma M, et al. Epstein-Barr virus in gastric carcinoma is associated with location in the cardia and with a diffuse histology: a study in one area of Chile. International journal of cancer. 2001;94(4):527-30. 
33. Chang MS, Lee HS, Kim CW, Kim YI, Kim WH. Clinicopathologic characteristics of Epstein-Barr virusincorporated gastric cancers in Korea. Pathology-Research and Practice. 2001;197(6):395-400.

34. Hao Z, Koriyama C, Akiba S, Li J, Luo X, Itoh T, et al. The Epstein-Barr virus-associated gastric carcinoma in Southern and Northern China. Oncology reports. 2002;9(6):1293-8.

35. Kattoor J, Koriyama C, Akiba S, Itoh T, Ding S, Eizuru Y, et al. Epstein-Barr virus-associated gastric carcinoma in southern India: A comparison with a large-scale Japanese series. Journal of medical virology. 2002;68(3):384-9.

36. Yaprak G, Tataroglu D, Dogan B, Pekyurek M. Prognostic factors for survival in patients with gastric cancer: Single-centre experience. Northern Clinics of Istanbul. 2020;7(2):146.

\section{Figures}

\section{Type of gastric cancer samples}

50

46

40

30

24

20

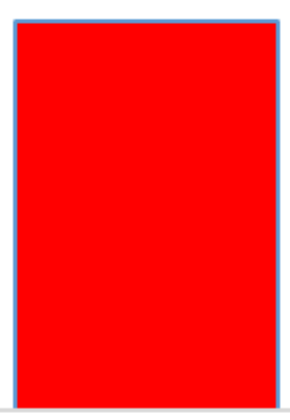

Diffuse type

Intestinal type

\section{Figure 1}

Frequency Types of Gastric Cancer Samples 


\section{Grades of gastric cancer samples}

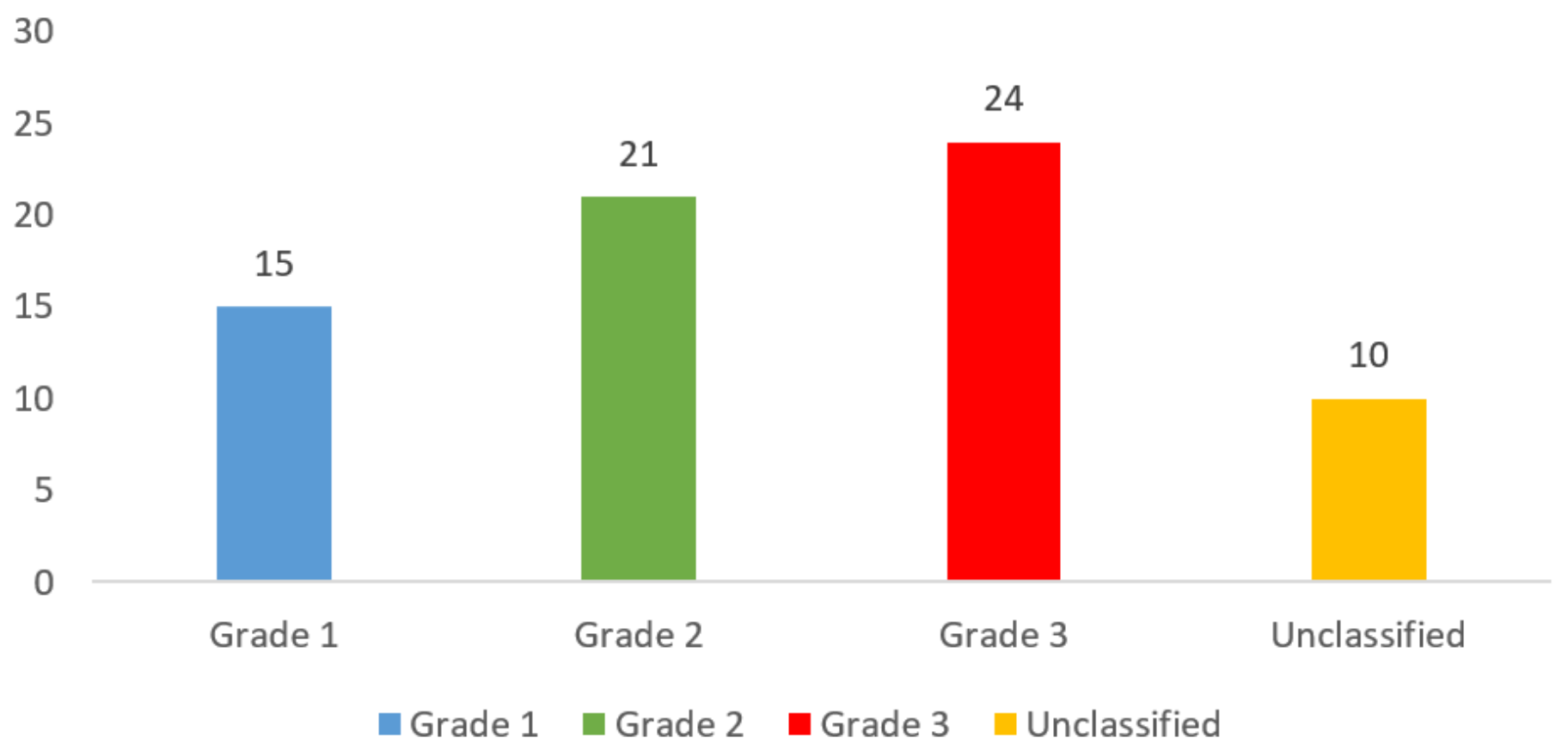

Figure 2

Frequency grades of Gastric Cancer Samples 


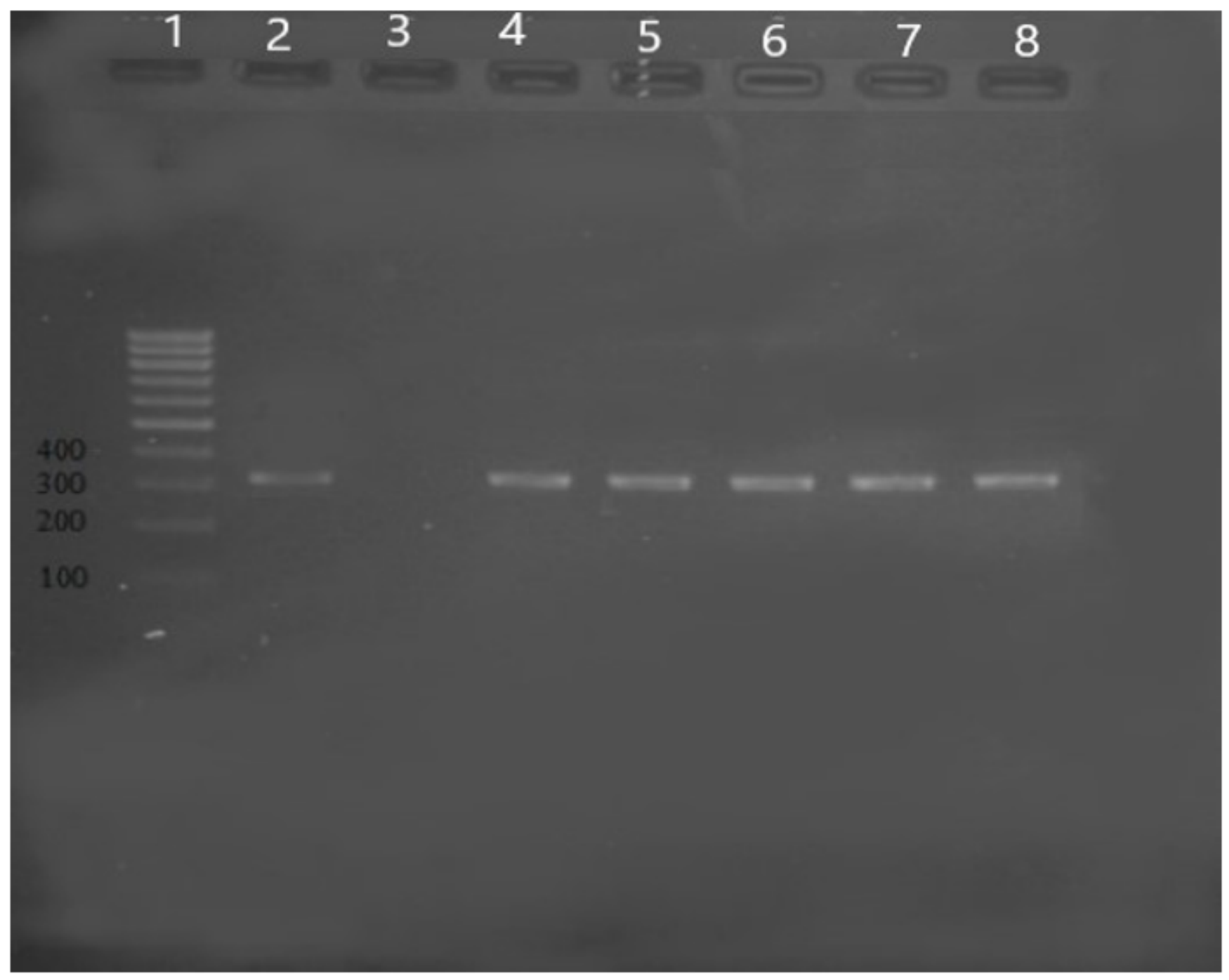

Figure 3

Analysis of EBV using the EBNA1 gene. Lane 1100 bp size marker, Lane 2 positive control (B95.8 cell line), Lane 3 negative control, Lane 4-8: EBV positive patients 


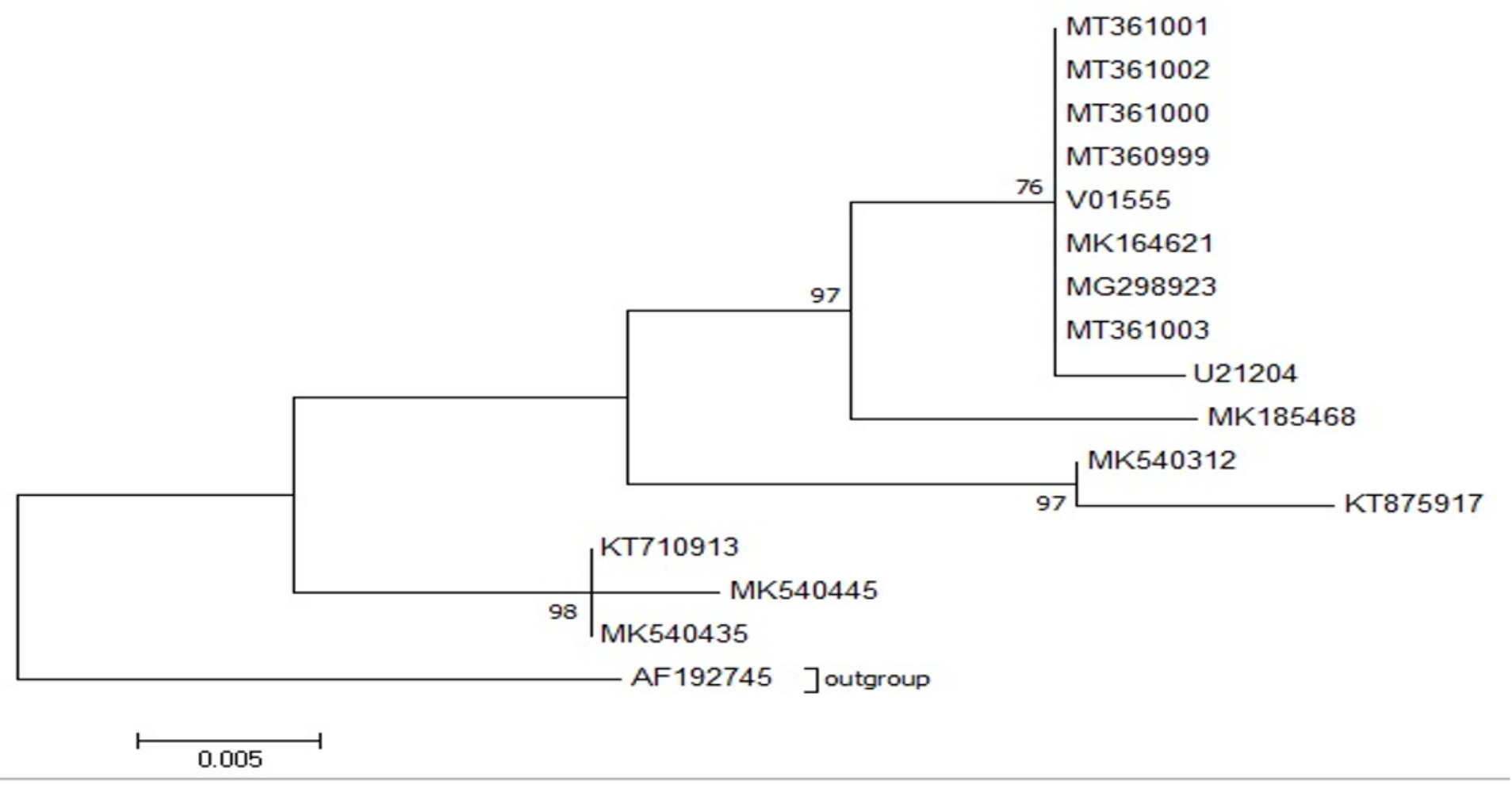

Figure 4

Molecular Phylogenetic analysis by Maximum Likelihood method

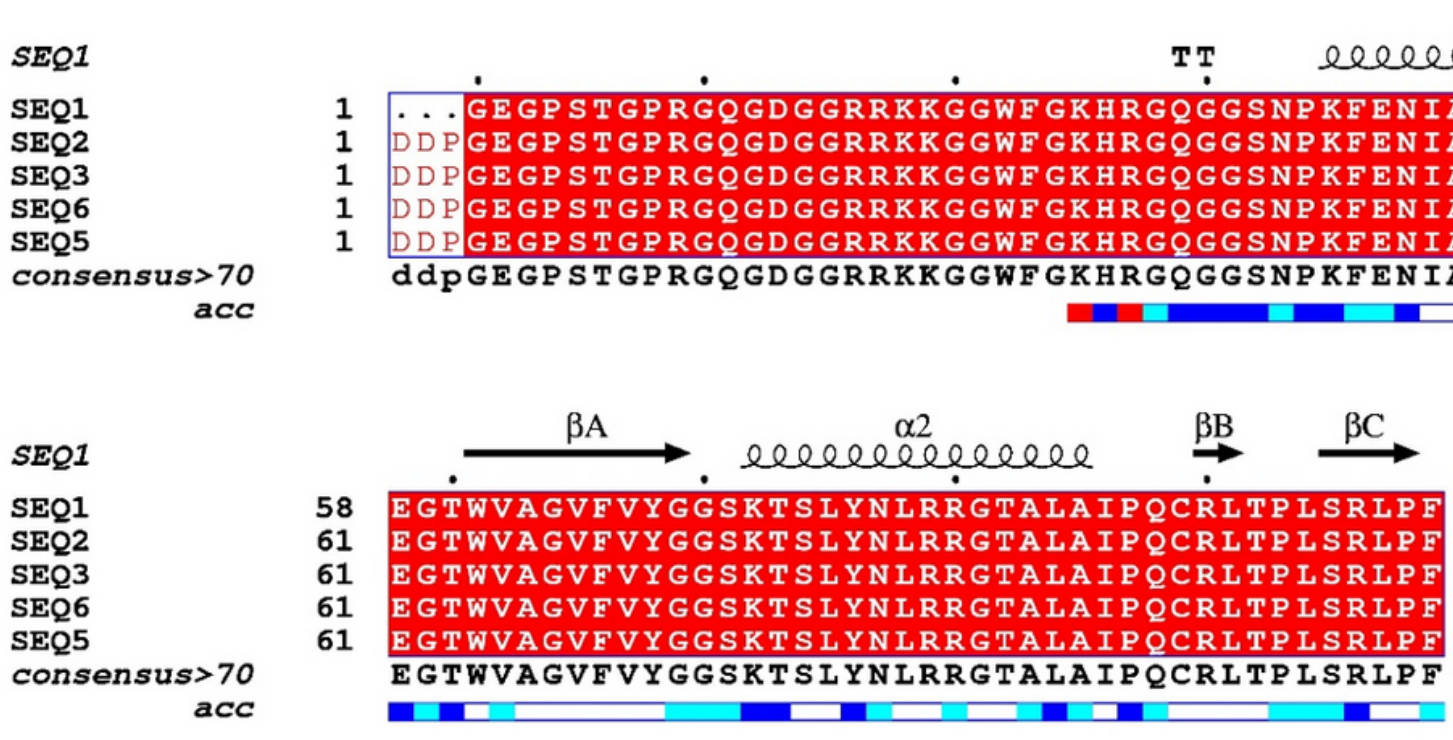

\section{Figure 5}

Comparison of the DNA sequence between EBNA 1 reference gene sequence and PCR amplicon of EBV positive samples in gastric cancer patients. DNA sequences of each sample and EBNA 1 reference gene sequence were the same. 